\title{
Anxiolytic-Like Properties of the Anandamide Transport Inhibitor AM404
}

\author{
Marco Bortolato',5, Patrizia Campolongo ${ }^{2,5}$, Regina Anne Mangieri', Maria Luisa Scattoni ${ }^{2}$, Roberto Frau ${ }^{3}$, \\ Viviana Trezza ${ }^{2}$, Giovanna La Rana ${ }^{4}$, Roberto Russo ${ }^{4}$, Antonio Calignano ${ }^{4}$, Gian Luigi Gessa ${ }^{3}$, \\ Vincenzo Cuomo ${ }^{2}$ and Daniele Piomelli*, I \\ 'Department of Psychiatry and Human Behavior, Center for Drug Discovery, University of California, Irvine, CA, USA; ${ }^{2}$ Department of Human \\ Physiology and Pharmacology, University of Rome 'La Sapienza', Rome, Italy; ' ${ }^{3}$ Department of Neuroscience 'Bernard B. Brodie', University of \\ Cagliari, Cagliari, Italy; ${ }^{4}$ Department of Experimental Pharmacology, University of Naples, Naples, Italy
}

\begin{abstract}
The endocannabinoids anandamide and 2-arachidonoyglycerol (2-AG) may contribute to the regulation of mood and emotion. In this study, we investigated the impact of the endocannabinoid transport inhibitor AM404 on three rat models of anxiety: elevated plus maze, defensive withdrawal and separation-induced ultrasonic vocalizations. AM404 (I-5 mg kg ${ }^{-1}$, intraperitoneal (i.p.)) exerted dosedependent anxiolytic-like effects in the three models. These behavioral effects were associated with increased levels of anandamide, but not 2-AG, in the prefrontal cortex and were prevented by the $C B_{1}$ cannabinoid antagonist rimonabant (SRI4I7I6A), suggesting that they were dependent on anandamide-mediated activation of $C_{1}$, cannabinoid receptors. We also evaluated whether $A M 404$ might influence motivation (in the conditioned place preference (CPP) test), sensory reactivity (acoustic startle reflex) and sensorimotor gating (prepulse inhibition (PPI) of the startle reflex). In the CPP test, AM404 (1.25-10 mg kg ${ }^{-1}$, i.p.) elicited rewarding effects in rats housed under enriched conditions, but not in rats kept in standard cages. Moreover, AM404 did not alter reactivity to sensory stimuli or cause overt perceptual distortion, as suggested by its lack of effect on startle or PPI of startle. These results support a role of anandamide in the regulation of emotion and point to the anandamide transport system as a potential target for anxiolytic drugs.

Neuropsychopharmacology (2006) 3 I, 2652-2659. doi: I0.1038/sj.npp. I 30106I; published online I5 March 2006
\end{abstract}

Keywords: anandamide; anxiety; AM404; conditioned place preference; prepulse inhibition

\section{INTRODUCTION}

The endogenous cannabinoid anandamide is removed from the synaptic space by a high-affinity transport system present in neural and non-neural cells (Di Marzo et al, 1994; Beltramo et al, 1997; Hillard et al, 1997). Although the molecular identity of this putative transporter remains unknown, its functional properties have been partially characterized (for review, see Hillard and Jarrahian, 2003). These include substrate saturation at $37^{\circ} \mathrm{C}$, stereoselective substrate recognition, independence from ion gradients, and pharmacological inhibition by agents such as $N$-(4-hydroxyphenyl)-arachidonamide (AM404), 5-biphenyl-4-ylmethyl-tetrazole-1-carboxylic acid dimethylamide (LY2183240), and $\mathrm{N}$-(3-furylmethyl)-arachidonamide

\footnotetext{
*Correspondence: Dr D Piomelli, Department of Pharmacology, 3101 Gillespie NRF, University of California, Irvine, CA 92697-4625, USA, Tel: + | 9498249179 , Fax: + | 9498246305 ,

E-mail: piomelli@uci.edu

${ }^{5}$ These authors contributed equally to this study.

Received 17 June 2005; revised 25 January 2006; accepted 26 January 2006

Online publication: I 5 February 2006 at http://www.acnp.org/citations/ Npp02 I 506050395/default.pdf
}

(UCM707) (Beltramo et al, 1997; Piomelli et al, 1999; de Lago et al, 2002; Moore et al, 2005). After internalization, anandamide is hydrolyzed by fatty-acid amide hydrolase (FAAH) (Désarnaud et al, 1995; Hillard et al, 1995; Ueda et al, 1995; Cravatt et al, 1996), an intracellular membrane-bound enzyme whose activity is selectively blocked by the compounds cyclohexylcarbamic acid 3'-carbamoylbiphenyl-3-yl ester (URB597) and 1-oxo-1-[5(2-pyridyl)oxazol-2-yl]-7-phenylheptane (OL-135) (Kathuria et al, 2003; Lichtman et al, 2004) as well as by other less selective inhibitors (for review, see Piomelli, 2005).

Along with subtype-preferring cannabinoid ligands (Palmer et al, 2002) and mutant FAAH-deficient mice (Cravatt et al, 2001), blockade of anandamide deactivation has helped reveal potential functions of this lipid molecule in the regulation of dopamine signaling and long-term synaptic plasticity in the striatum (Giuffrida et al, 1999; Beltramo et al, 2000; Gerdeman et al, 2002; Azad et al, 2004) as well as acetylcholine signaling in the neocortex and hippocampus (Gifford et al, 1999; Tzavara et al, 2003; Steffens et al, 2003). Moreover, the hypoalgesic phenotype of FAAH-deficient mice (Cravatt et al, 2001) and the ability of FAAH inhibitors to alleviate pain, anxiety, and depression in rodent models (Kathuria et al, 2003; Lichtman et al, 
2004; Hohmann et al, 2005; Gobbi et al, 2005) suggest that anandamide modulates the activity of neural circuits involved in the control of nociception, stress and emotion. These findings raise two clinically relevant questions. The first is whether inhibitors of endocannabinoid transport, which prolong anandamide's actions by preventing its access to intracellular FAAH (Beltramo et al, 1997; Kathuria et al, 2003), may exert anxiolytic-like effects. The second is whether such effects, if present, may be associated with other consequences of $\mathrm{CB}_{1}$ receptor activation, such as perceptual distortion and liability to addiction (Hollister, 1998; D'Souza et al, 2005). To begin to address these issues, in the present study we have investigated the impact of a prototypical anandamide transport inhibitor, the compound AM404, on a series of behavioral models relevant to potential emotional and cognitive outcomes of endocannabinoid deactivation blockade.

\section{MATERIALS AND METHODS}

\section{Animals}

We used 10-day old Wistar pups for ultrasonic vocalization emission tests, adult male Sprague-Dawley rats (250-300 g) for startle and prepulse inhibition (PPI) tests, and adult male Wistar rats (200-350 g) for all other tests. Some of the rats tested for conditioned place preference (CPP) were housed under enriched conditions, consisting in exposing the rats for 6 weeks to a varied set of daily exchanged toys in a structured cage environment, as well as daily handling sessions. All procedures met the National Institutes of Health guidelines for the care and use of laboratory animals and those of the Italian Ministry of Health (D.L. 116/92).

\section{Drugs}

AM404 and WIN55,212-2 were from Tocris Cookson (Avonmouth, UK); morphine, diazepam, apomorphine and dizocilpine (MK801) from Sigma Aldrich (St Louis, USA); and rimonabant (SR141716A) from the National Institute on Drug Abuse (NIDA).

\section{Endocannabinoid Analyses}

At $45 \mathrm{~min}$ after injection with AM404 (2.5-10 $\mathrm{mg} \mathrm{kg}^{-1}$, intraperitoneal (i.p.)) or vehicle (polyethylene glycol, Tween 80 , saline solution; 5:5:90 vol/ $\mathrm{vol}$ ), we anesthetized the rats with halothane and promptly decapitated them with a guillotine. Brains were removed within approximately $1 \mathrm{~min}$ after decapitation, frozen in 2-methylbutane and stored at $-80^{\circ} \mathrm{C}$ until analysis. We placed frozen brains on a cutting block and sliced them into $1 \mathrm{~mm}$ sections. Prefrontal cortex was taken from approximately 2.20 to $4.20 \mathrm{~mm}$ rostral to bregma. Hippocampus was dissected from approximately 2.20 to $6.20 \mathrm{~mm}$ caudal to bregma. Thalamus was dissected from approximately 2.20 to $4.20 \mathrm{~mm}$ caudal to bregma. Tissues were immediately frozen on dry ice and stored at $-80^{\circ} \mathrm{C}$ until analysis. We extracted endocannabinoids and related lipids with methanol-chloroform, fractionated them by open-bed silica gel chromatography and quantified them by isotope-dilution liquid chromatography/mass spectrometry (LC/MS), as described by Fegley et al (2004).

\section{Elevated Plus Maze}

Adult Wistar rats were placed in the central platform of the test apparatus (Pellow et al, 1985) and video recorded for $5 \mathrm{~min}$ in a dim light, sound-attenuated environment. The maze comprised two open arms $\left(50 \times 10 \mathrm{~cm}^{2}\right)$ and two closed arms $\left(50 \times 10 \times 40 \mathrm{~cm}^{3}\right)$ that extended from a common central platform $\left(10 \times 10 \mathrm{~cm}^{2}\right)$. The apparatus, made of Plexiglas (gray floor, clear walls), was elevated to a height of $60 \mathrm{~cm}$ above the floor level. AM404 and vehicle were injected $30 \mathrm{~min}$ before testing. Behavioral analyses were performed by blinded observers, using the Observer 3.0 software (Noldus, Wageningen, the Netherlands). Percent time spent in open arms, number of head dips and stretched attend postures were measured as described by Griebel et al (2002).

\section{Defensive Withdrawal}

At $45 \mathrm{~min}$ after treatment, adult Wistar rats were placed in a small cylindrical stainless-steel chamber $(11 \mathrm{~cm}$ diameter $\times 21 \mathrm{~cm}$ length) opened at one end, alongside one of the four walls of an open field $\left(90 \times 90 \mathrm{~cm}^{2}\right)$ (Takahashi et al, 2001), and video recorded for $15 \mathrm{~min}$ in a dim light, sound-attenuated environment. Behavioral analyses were performed by blinded observers, using the Observer 3.0 software (Noldus, Wageningen, the Netherlands). The latency to leave the chamber and the total amount of time spent in the open field were measured.

\section{Isolation-Induced Ultrasonic Vocalizations}

Vocalizations were recorded in 10-day-old Wistar rat pups, as described by Cagiano et al (1988). Briefly, a single male pup was randomly removed from each litter, weighed and placed in a shallow glass dish located $15 \mathrm{~cm}$ under a microphone, connected to a sound detector. Vocalizations were recorded $30 \mathrm{~min}$ after treatment, for $15 \mathrm{~s}$ and expressed as percent change from baseline.

\section{Startle and PPI of Startle}

The startle reflex was assessed as described by Bortolato et al (2005). At $45 \mathrm{~min}$ after treatment with either AM404 or vehicle, rats were placed in a startle reflex apparatus (Med Associates, St Albans, USA) for a $5 \mathrm{~min}$ acclimatization period with a $70 \mathrm{~dB}$ background noise, which continued for the remainder of the session. Each session consisted of three consecutive sequences of trials. During the first and the third sequence, the rats were presented with five pulse-alone trials of $115 \mathrm{~dB}$. The second sequence consisted of 50 trials in pseudo-random order, including 12 pulse-alone trials, 30 trials of pulse preceded by 73,76 , or $82 \mathrm{~dB}$ prepulses (10 for each level of prepulse loudness), and eight no stimulus trials, where only the background noise was delivered. Intertrial intervals were selected randomly between 10 and $15 \mathrm{~s}$. Acoustic devices and startle cages were connected to a computer, which detected and analyzed all chamber variables using customized software. Percent PPI was calculated with the following formula: $100-[$ (mean startle amplitude for prepulse-pulse trials/mean startle amplitude for pulse-alone trials) $\times 100]$. 


\section{CPP}

CPP was evaluated as described by Gobbi et al (2005). The experiment consisted of three consecutive phases. The CPP apparatus consisted of four rectangular plastic shuttle boxes $\left(30 \times 60 \times 30 \mathrm{~cm}^{3}\right)$, each divided by a guillotine door into two distinct compartments of equal size, containing different visual and tactile cues. Visual cues were present on the walls, which were either brown or black and white striped; tactile cues were present in the floor, being either grid or chequered. All cues were present in the compartments in a counterbalanced order. The experimental room was sound attenuated and dimly lit. In phase I the animals were habituated to CPP boxes for 3 days and their initial side preferences were recorded. Phase II lasted 12 days and consisted of six alterned presentations of AM404 $\left(1.25-10 \mathrm{mg} \mathrm{kg}^{-1}\right.$, i.p.), WIN55,212-2 (1 $\mathrm{mg} \mathrm{kg}^{-1}$, i.p.) or morphine $\left(5 \mathrm{mg} \mathrm{kg}^{-1}\right.$, s.c.) and vehicle. Specifically, on odd days rats received one of the drugs or vehicle and were immediately placed in the nonpreferred compartment (separated from the other by a guillotine door) for $60 \mathrm{~min}$, while on even days rats received vehicle and were placed in the preferred compartment for $60 \mathrm{~min}$. On the test day (phase III), the animals were given no treatment and were placed in the cage with free access to both sides for $15 \mathrm{~min}$. Drug-induced differences were assessed from the time spent in the nonpreferred compartment between postconditioning and preconditioning tests. Since environmental enrichment has been shown to positively affect mood and cognitive abilities in rats (Larsson et al, 2002; Renner and Rosenzweig, 1987), we conducted CPP tests in animals housed under both standard and enriched conditions.

\section{Statistical Analyses}

Results are expressed as the mean \pm SEM of $n$ experiments. All analyses were conducted using Statistica (Statsoft, Tulsa, USA). The significance of differences between groups was determined by one- or two-way analysis of variance (ANOVA) followed by Tukey's or Spjotvoll-Stoline's tests for multiple comparisons, as appropriate.

\section{RESULTS}

\section{Effects of AM404 on Anandamide Levels in the Brain}

The inhibitory effects of AM404 on anandamide transport have been previously characterized both in vitro and in vivo (Beltramo et al, 1997, 2000; Piomelli et al, 1999; Fegley et al, 2004). To assess its impact on brain anandamide levels, we administered AM404 to adult Wistar rats and measured endocannabinoid content in the prefrontal cortex, hippocampus and thalamus by LC/MS $45 \mathrm{~min}$ after injection. AM404 caused a dose-dependent increase in anandamide levels in prefrontal cortex $\left(\mathrm{F}_{4,41}=3.72, p<0.05 ; p<0.05\right.$ for post hoc comparisons between vehicle and AM404 $\left.5 \mathrm{mg} \mathrm{kg}^{-1}\right)$, hippocampus $\left(\mathrm{F}_{4,37}=7.73, p<0.001 ; p<0.001\right.$ for post hoc comparisons between vehicle and AM404 $\left.10 \mathrm{mg} \mathrm{kg}^{-1}\right)$ and thalamus $\left(\mathrm{F}_{4,25}=3.12, p<0.05 ; p<0.05\right.$ for post hoc comparisons between vehicle and AM404 $10 \mathrm{mg} \mathrm{kg}^{-1}$ ) (Figure $1 \mathrm{a}-\mathrm{c}$ ). In contrast, the drug had no effect on the levels of 2-arachidonoyglycerol (2-AG),
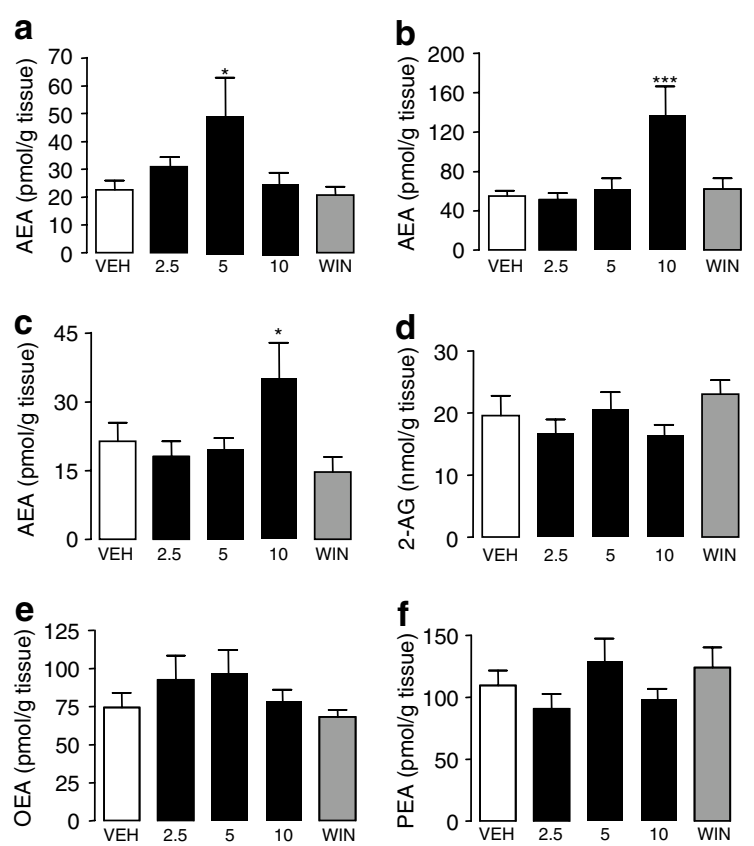

Figure I Levels of endocannabinoids and related compounds in select regions of the rat brain following administration of AM404 $\left(2.5-10 \mathrm{mg} \mathrm{kg}^{-1}\right.$, i.p.) or WIN55,2 I2-2 (WIN, I mg kg-1, i.p.). Levels of anandamide (AEA) in (a) prefrontal cortex, (b) hippocampus, and (c) thalamus; levels of (d) 2 $A G$, (e) OEA, and (f) PEA in prefrontal cortex. Drugs were injected $45 \mathrm{~min}$ before killing. Results are expressed as mean \pm SEM. Doses are in $\mathrm{mg} \mathrm{kg}{ }^{-1}$ ${ }^{*} p<0.05$, **** $p<0.001$ compared to vehicle $(\mathrm{VEH}) ; n=6-12$ per group.

oleoylethanolamide (OEA) and palmitoylethanolamide (PEA) in any of the brain regions examined (Figure $1 \mathrm{~d}-\mathrm{f}$ and data not shown). As OEA and PEA are two FAAH substrates, which are markedly elevated after administration of FAAH inhibitors (Fegley et al, 2005), the present results confirm that AM404 does not affect FAAH activity in vivo (Fegley et al, 2004). As expected, the direct-acting cannabinoid agonist WIN55,212-2 (1 $\mathrm{mg} \mathrm{kg}^{-1}$, i.p.) had no effect on brain anandamide content (Figure 1a-c).

\section{Effects of AM404 in the Elevated Plus Maze Test}

Next, we examined whether the ability of AM404 to increase anandamide levels in the brain might be associated with a modulation of anxiety responses, as previously shown for the FAAH inhibitor URB597 (Kathuria et al, 2003). In a preliminary open field test, Wistar rats received different doses of AM404 (1-10 mg-kg ${ }^{-1}$, i.p., 30 min before trials) to assess the effects of this drug on locomotor and exploratory activities. In agreement with previous results (Beltramo et al, 2000), only the dose of $10 \mathrm{mg} \mathrm{kg}^{-1}$ was found to elicit a significant reduction of locomotor activity (number of crossings: vehicle: $71.5 \pm 7.9$; AM404 $2.5 \mathrm{mg} \mathrm{kg}^{-1}: 64.1 \pm 9.3$; AM404 $5 \mathrm{mg} \mathrm{kg}^{-1}: 62.3 \pm 11.2$; AM404 $10 \mathrm{mg} \mathrm{kg}^{-1}: 46.2 \pm 7.8$, $p<0.05$ in comparison with vehicle; $n=11-16$ per group; session duration: $10 \mathrm{~min}$ ). We then tested the effects of AM404 in the elevated plus maze (Pellow et al, 1985). Rats treated with doses of AM404 that did not affect locomotor activity $\left(0.5-5 \mathrm{mg} \mathrm{kg}^{-1}\right.$, i.p., $30 \mathrm{~min}$ before trials) spent a longer time in the open arm of the plus maze than did vehicle-injected rats (Figure $2 \mathrm{a}) \quad\left(\mathrm{F}_{5,53}=6.21, p<0.001\right.$; 
$p<0.05$ for post hoc comparisons between vehicle and AM404 $5 \mathrm{mg} \mathrm{kg}^{-1}$ ). The clinically used anxiolytic diazepam produced a similar effect at the i.p. doses of $2.5 \mathrm{mg} \mathrm{kg}^{-1}$ (Figure 2a) and $5 \mathrm{mg} \mathrm{kg}^{-1}$ (data not shown). Moreover, AM404-treated animals exhibited a higher number of head dips (Figure 2b) $\left(\mathrm{F}_{5,53}=5.86, p<0.001 ; p<0.01\right.$ for post hoc comparisons between vehicle and AM404 $5 \mathrm{mg} \mathrm{kg}^{-1}$ ) along with a lower frequency of stretched attend postures (Figure $2 \mathrm{c})\left(\mathrm{F}_{5,53}=9.52, p<0.001 ; p<0.01\right.$ for post hoc comparisons between vehicle and AM404 $5 \mathrm{mg} \mathrm{kg}^{-1}$ ). Importantly, a nonanxiogenic dose of the $\mathrm{CB}_{1}$ receptor antagonist rimonabant $\left(1 \mathrm{mg} \mathrm{kg}^{-1}\right.$, i.p.) prevented all anxiolytic-like effects of AM404 (Figure 2d-f) (open arms time: $\mathrm{F}_{3,36}=4.523, p<0.01$; head dips: $\mathrm{F}_{3,36}=4.79 p<0.01$; stretched attend postures: $\mathrm{F}_{3,36}=2.82, p<0.05$ ), indicating that such effects were mediated by $\mathrm{CB}_{1}$ receptors.

\section{Effects of AM404 on Defensive Withdrawal}

As an additional test of the anxiolytic-like properties of AM404, we evaluated the effects of this agent on defensive
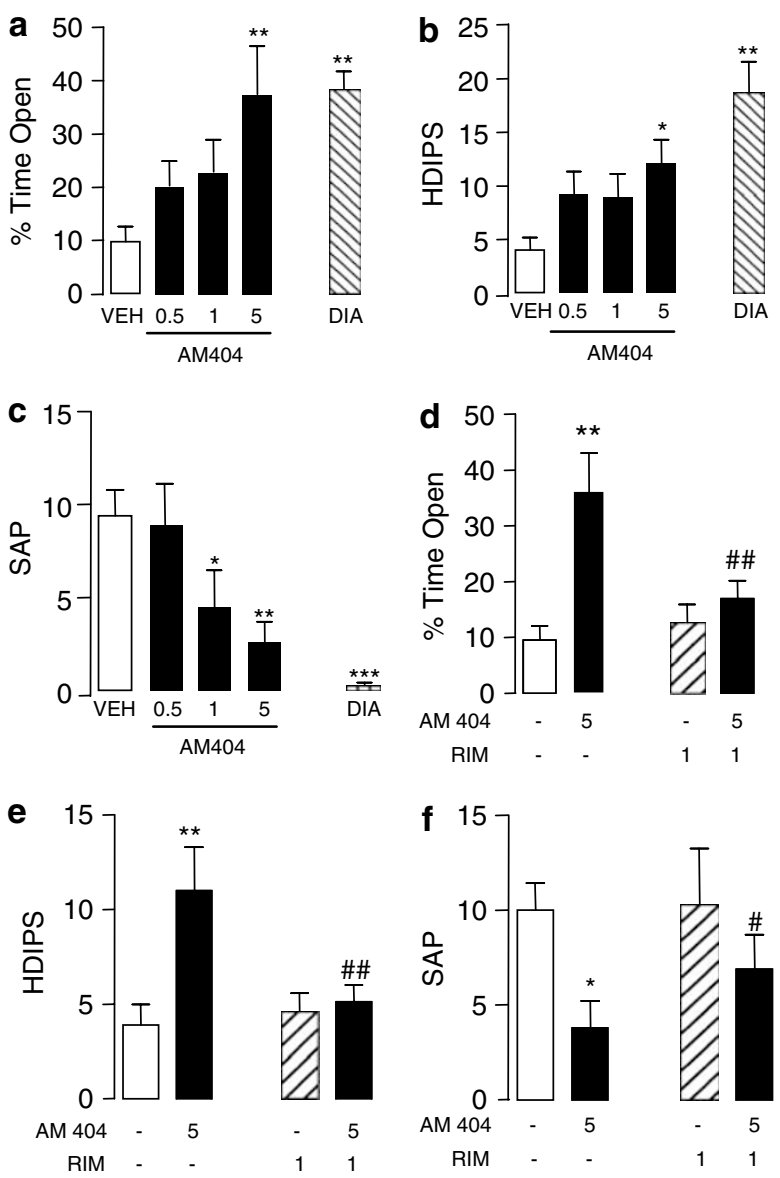

Figure 2 Effects of AM404 (0.5-5 $\mathrm{mg} \mathrm{kg}^{-1}$, i.p.) or diazepam (DIA, $2.5 \mathrm{mg} \mathrm{kg}^{-1}$, i.p.) in the rat elevated plus maze test, and reversal of these effects by rimonabant (RIM). (a and d) AM404 and diazepam were injected 30 and $60 \mathrm{~min}$ before testing, respectively. Percent time spent in the open arms (\%time open); ( $b$ and e) Number of head dips (HDIPS); ( $c$ and $f$ ) Number of stretched attend postures (SAP). ${ }^{*} p<0.05, * * p<0.01$ compared to vehicle $(\mathrm{VEH})$; ${ }^{* * * *} p<0.00 \mathrm{I} ;{ }^{\#} p<0.05 ;{ }^{\# \#} p<0.0$ I compared to AM404 $5 \mathrm{mg} \mathrm{kg}^{-1} ; n=8-$ II per group. withdrawal in Wistar rats (Takahashi et al, 2001). AM404 $\left(1-5 \mathrm{mg} \mathrm{kg}^{-1}\right.$, i.p.) elicited a dose-dependent increase in time spent outside the box (Figure $3 \mathrm{a})\left(\mathrm{F}_{2,27}=3.57, p<0.05\right)$ and a dose-dependent decrease in latency to leave the box (Figure $3 b)\left(\mathrm{F}_{2,27}=4.18, p<0.05\right)$. Both responses were significantly reduced by rimonabant $\left(1 \mathrm{mg} \mathrm{kg}^{-1}\right.$, i.p. $)$ (Figure 3a and b) (total time: $\mathrm{F}_{3,36}=3.69, p<0.05$; latency: $\left.\mathrm{F}_{3,36}=2.93, p<0.05\right)$.

\section{Effects of AM404 on Ultrasonic Vocalization Test}

Concurrent results were obtained in the ultrasonic vocalization test in Wistar rat pups (Cagiano et al, 1988). In this test, AM404 (0.5-5 $\mathrm{mg} \mathrm{kg}^{-1}$, i.p.) exerted anxiolytic-like effects (Figure $3 c)\left(\mathrm{F}_{5,60}=4.85, p<0.001, p<0.05\right.$ for post hoc comparisons between vehicle and AM404 $1 \mathrm{mg} \mathrm{kg}^{-1}$; $p<0.01$ for post-hoc comparisons between vehicle and AM404 $2 \mathrm{mg} \mathrm{kg}^{-1}$ ) at doses that did not alter axillary temperature or locomotor activity (data not shown). These responses were comparable to those produced by diazepam $\left(0.25 \mathrm{mg} \mathrm{kg}^{-1}\right.$, i.p.) $(p<0.01$; data not shown), and were abrogated by rimonabant $\left(1 \mathrm{mg} \mathrm{kg}^{-1}\right.$, i.p.) (Figure 3c) $\left(\mathrm{F}_{3,24}=6.54, p<0.001\right)$. The inverse $\mathrm{U}$-shaped effect of
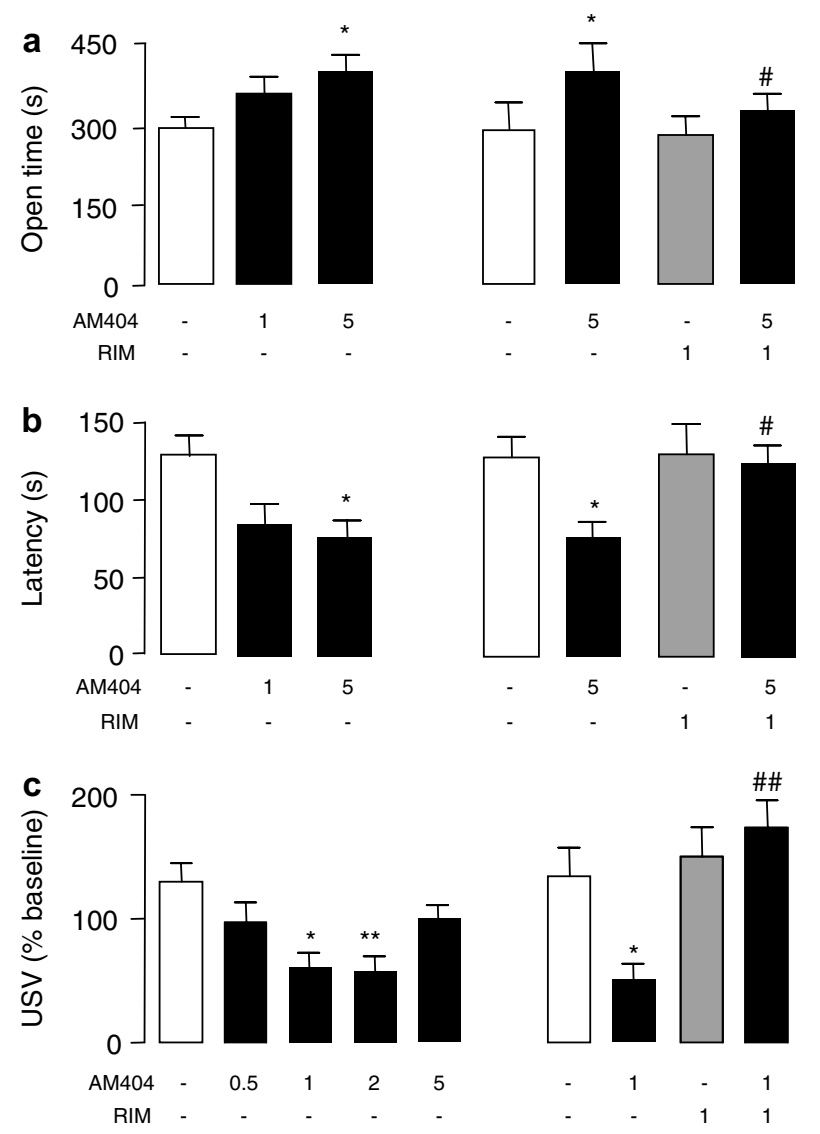

Figure 3 Effects of AM404 ( $1-5 \mathrm{mg} \mathrm{kg}^{-1}$, i.p.) in the (a-b) rat defensive withdrawal and (c) ultrasonic vocalization tests, and reversal of these effects by rimonabant (RIM). (a) Time spent outside the box; (b) Latency to leave the box; (c) Ultrasonic vocalizations in 10 -day old rat pups. $* 2<0.05$, ${ }^{* *} p<0.0$ I compared to vehicle (VEH); ${ }^{\#} p<0.05 ;{ }^{\# \#} p<0.0$ l compared to AM404 $\left(5 \mathrm{mg} \mathrm{kg}^{-1}\right.$ in defensive withdrawal and $1 \mathrm{mg} \mathrm{kg}^{-1}$ in ultrasonic vocalizations); $n=10-12$ per group. 
AM404 observed in this test was likely due to a greater sensitivity of the pups to the effects of the drug.

\section{Effects of AM404 on Startle and PPI of Startle}

To determine whether the anxiolytic-like actions of AM404 might be associated with altered vigilance and reactivity to sensory stimuli, a common effect of both anxiolytic drugs and cannabinoid agonists (Koelega, 1989; Bahri and Amir, 1994), we measured startle magnitude in Sprague-Dawley rats after administration of AM404 $\left(2.5-10 \mathrm{mg} \mathrm{kg}^{-1}\right.$, i.p. $)$, WIN55,212-2 (5 mg kg${ }^{-1}$, i.p.) or diazepam $\left(2.5-5 \mathrm{mg} \mathrm{kg}^{-1}\right.$, i.p.). Diazepam increased startle latency at the 2.5 and $5 \mathrm{mg} \mathrm{kg}^{-1}$ doses (data not shown), and decreased startle amplitude at the dose of $5 \mathrm{mg} \mathrm{kg}^{-1}$ (Figure 4a). WIN55,2122 produced a significant reduction of startle amplitude, but did not affect startle latency (Figure $4 \mathrm{a}$ and data not shown) $\left(\mathrm{F}_{5,62}=4.2, p<0.01, p<0.05\right.$ for post hoc comparisons between diazepam and vehicle and WIN55,212-2 and vehicle) (Bortolato et al, 2005; Abduljawad et al, 1997). By contrast, AM404 did not affect any startle-related parameter at the doses tested (Figure $4 \mathrm{a}$ ). We then examined the impact of AM404 (2.5-10 $\mathrm{mg} \mathrm{kg}^{-1}$, i.p.) on PPI of the startle reflex, the disruption of which is widely utilized as a model of perceptual distortion (Swerdlow et al, 2000). We compared the effects of AM404 with those of WIN55,212-2 $\left(1 \mathrm{mg} \mathrm{kg}^{-1}\right.$, i.p. $)$, apomorphine $\left(0.25 \mathrm{mg} \mathrm{kg}^{-1}\right.$, s.c. $)$ and
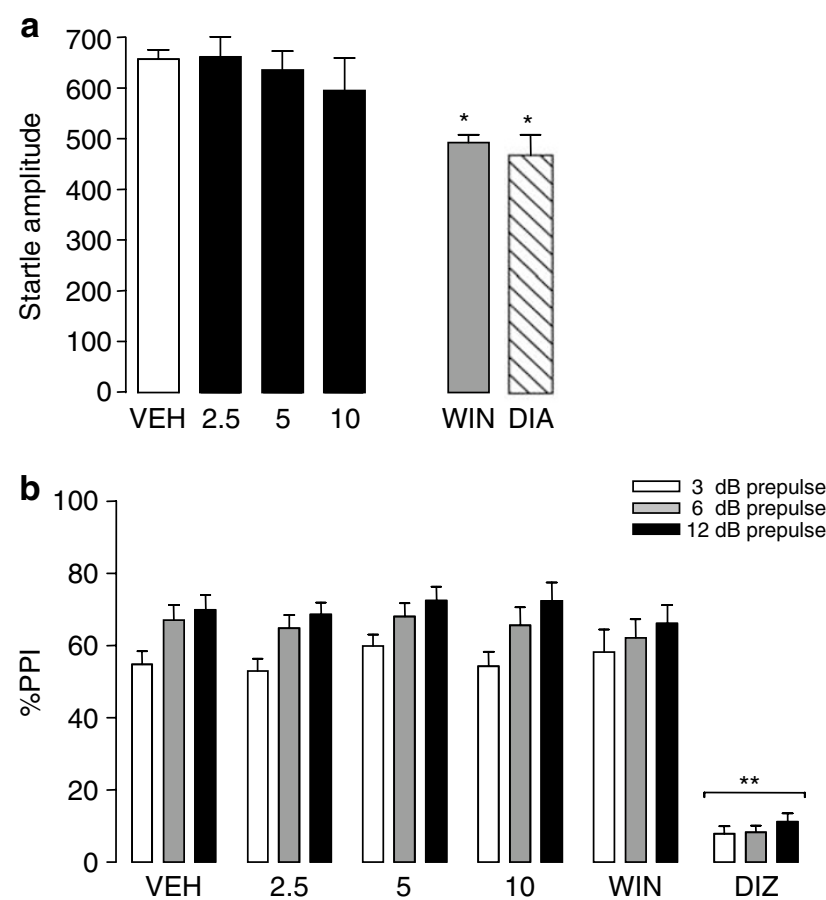

Figure 4 Effects of AM404 on (a) startle amplitude and (b) PPI in rats. (a) Effects of AM404 (2.5-10 $\mathrm{mg} \mathrm{kg}^{-1}$, i.p.), WIN55,212-2 (WIN, $1 \mathrm{mg} \mathrm{kg}^{-1}$, i.p.) and diazepam (DIA, $5 \mathrm{mg} \mathrm{kg}^{-1}$, i.p.) on startle reflex amplitude; * $p<0.05$ compared with vehicle (VEH); (b) Effects of AM404 (2.5-10 $\mathrm{mg} \mathrm{kg}^{-1}$, i.p.), WIN55,212-2 (I mg kg-1, i.p.) and dizocilpine (DIZ, $0.1 \mathrm{mg} \mathrm{kg}^{-1}$, s.c.) on PPI. AM404 and WIN55,2I 2-2 were injected $45 \mathrm{~min}$ before testing, while diazepam and dizocilpine was injected 60 and 5 min before testing, respectively. Prepulse intensity is expressed in decibels above background noise. ${ }^{*} p<0.05$, ${ }^{*} * p<0.0$ I compared with vehicle; $n=8-11$ per group. dizocilpine $\left(0.1 \mathrm{mg} \mathrm{kg}^{-1}\right.$, s.c.). AM404 was ineffective in this test at all doses examined (Figure $4 \mathrm{~b}$ ). As previously shown, WIN55,212-2 was also unable to disrupt PPI (Bortolato et al, 2005), while dizocilpine significantly decreased it (Figure $4 \mathrm{~b})\left(\mathrm{F}_{2,38}=5.26 ; p<0.01\right)$; a similar decrease was observed with apomorphine $\left(\mathrm{F}_{2,38}=3.77\right.$; $p<0.05$ ) (data not shown).

\section{Effects of AM404 on CPP}

Finally, we examined the motivational effects of AM404 in the CPP test, and compared them to those produced by WIN55,212-2 (1 $\mathrm{mg} \mathrm{kg}^{-1}$, i.p.) and morphine $\left(5 \mathrm{mg} \mathrm{kg}^{-1}\right.$, s.c. $)$. As shown in Figure 5a, Wistar rats housed under standard nonenriched conditions exhibited a significant shift in preference towards the morphine-associated compartments $\left(\mathrm{F}_{6,48}=6.89, p<0.001\right.$ for main treatment effect; $p<0.05$ for post hoc comparison between vehicle and morphine), but not to the compartments associated with either AM404 (1.25$10 \mathrm{mg} \mathrm{kg}^{-1}$, i.p.) or WIN55,212-2. In contrast, rats housed under enriched conditions displayed a significant shift in preference toward the environment associated with AM404, WIN55,212-2, or morphine (Figure 5b). In particular, enriched AM404-treated rats $\left(1.25-10 \mathrm{mg} \mathrm{kg}^{-1}\right.$, i.p.) exhibited a dose-dependent shift in preference, which was significantly higher than controls for the $2.5 \mathrm{mg} \mathrm{kg}^{-1}$ dose (Figure $5 \mathrm{~b}$ )
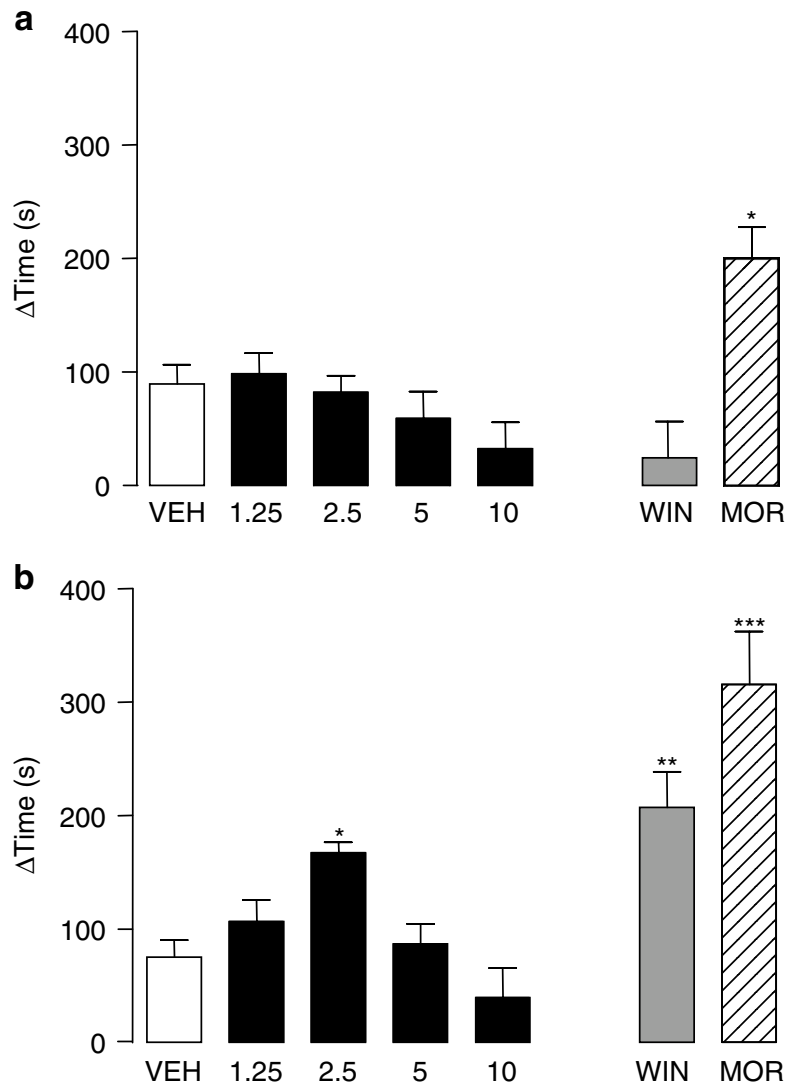

Figure 5 Effects of AM404 (1.25-10 mg kg-1, i.p.), WIN55,2 I 2-2 (WIN, $1 \mathrm{mg} \mathrm{kg}{ }^{-1}$, i.p.), morphine (MOR, $5 \mathrm{mg} \mathrm{kg}^{-9}$, s.c.) in the CPP test performed in rats housed under (a) enriched or (b) nonenriched conditions. ${ }^{*} p<0.05$, *** $p<0.0$ I, **** $p<0.00$ I in comparison with vehicle $(V E H) ; n=8-12$ per group. 
$\left(\mathrm{F}_{6,59}=8.86, p<0.001\right.$ for main treatment effect; $p<0.05$ for post hoc comparison between vehicle and AM404 $2.5 \mathrm{mg} \mathrm{kg}^{-1}$ $p<0.01$ for post hoc comparison between vehicle and WIN55,212-2; $p<0.001$ for post hoc comparison between vehicle and morphine). Statistical analysis indicated, however, that the preference shift induced by $2.5 \mathrm{mg} \mathrm{kg}^{-1}$ AM404 was significantly lower than that elicited by $5 \mathrm{mg} \mathrm{kg}^{-1}$ morphine $(p<0.001$, Tukey's test $)$.

\section{DISCUSSION}

The present study shows that the endocannabinoid transport inhibitor AM404 selectively increases levels of anandamide, but not 2-AG, in the rat prefrontal cortex, hippocampus and thalamus, three brain regions that are intimately involved in the regulation of stress and emotion (Nestler et al, 2002; Cahill and McGaugh, 1998). This biochemical response is accompanied by marked anxiolyticlike effects, which are prevented by the $\mathrm{CB}_{1}$ receptor antagonist rimonabant. In contrast, AM404 exerts only modest motivational effects in the CPP test and does not influence startle reflex or PPI of startle.

The anxiolytic-like effects elicited by AM404 and the sensitivity of these effects to rimonabant suggest that endogenously produced anandamide is involved in the regulation of anxiety, plausibly via activation of brain $\mathrm{CB}_{1}$ receptors. Such a mechanism might also account for the antidepressant-like effects of AM404, which were recently documented using the rat forced-swim test (Hill and Gorzalka, 2005). Our results complement other lines of evidence suggesting a role for anandamide in the modulation of emotional responses to stress. Stressful stimuli affect anandamide mobilization in brain regions that are involved in the control of emotion. In rats, for example, a single electric shock to the paw elevates anandamide levels in the midbrain (Hohmann et al, 2005), while in mice physical restraint decreases anandamide levels in the amygdala (Patel et al, 2004). Moreover, pharmacological blockade or genetic ablation of $\mathrm{CB}_{1}$ receptors exacerbates normal reactions to acute stress, presumably by disabling an endocannabinoid modulation of these reactions (Navarro et al, 1997; Haller et al, 2004; Urigüen et al, 2004). Finally, the FAAH inhibitor URB597 enhances stress-coping behaviors in a rimonabant-sensitive manner (Kathuria et al, 2003; Gobbi et al, 2005), suggesting that anandamide interacts with a subgroup of $\mathrm{CB}_{1}$ receptors in the brain that regulate stress responses.

Brain $\mathrm{CB}_{1}$ receptors are predominantly localized on axon terminals of $\gamma$-amino-butyric acid (GABA)ergic and glutamatergic neurons, and their activation inhibits the release of GABA and glutamate in the hippocampus, amygdala and other regions of the brain (for review, see Freund et al, 2003). Thus, the modulation of either inhibitory or excitatory transmitter systems may be involved in the regulation of emotional behavior by anandamide. In addition, anandamide might also influence the release of anxiogenic neuropeptides, such as corticotropin-releasing factor and cholecystokinin-octapeptide (Weidenfeld et al, 1994; Beinfeld and Connolly, 2001).

In contrast with previous experiments in mice (Fernandez-Espejo and Galan-Rodriguez, 2004), we found that
AM404 does not affect startle reflex and PPI in SpragueDawley rats. Differences in animal species and experimental protocol are likely to account for this discrepancy. For example, those studies were performed in a local colony of Swiss mice, which did not show either loudness dependence in baseline PPI or dose dependence in PPI disruption induced by acute administration of AM404. Irrespective of possible explanations, our findings clearly indicate that blockade of anandamide transport has little impact on sensory reactivity in Sprague-Dawley rats. Moreover, since PPI disruption is considered to be a predictor of perceptual impairment and hallucinatory potential (Swerdlow et al, 2000), the results also suggest that AM404 may be devoid of acute psychotomimetic effects.

AM404 produced an inverse U-shaped response in the CPP paradigm, but only when administered to rats housed under enriched conditions. At the dose of $2.5 \mathrm{mg} \mathrm{kg}^{-1}$, the effect of AM404 was similar to that elicited by the directacting cannabinoid agonist WIN55,212-2, albeit lower than that produced by morphine. Conversely, no response to either AM404 or WIN55,212-2 was observed in rats kept under nonenriched conditions. These results are consistent with those of other investigations, showing that environmental factors can greatly affect responses in the CPP test (Bowling and Bardo, 1994; Smith et al, 2003). As such, they might help interpret some of the discrepancies reported on the effects of cannabinoid agonists in this model (Gardner, 2005). In addition, our findings are consistent with recent findings indicating that both anandamide (Justinova et al, 2005) and AM404 are intravenously self-administered by squirrel monkeys (Justinova and Goldberg, 2005).

Previous reports have shown that AM404 does not closely mimic the spectrum of pharmacological responses produced by direct cannabinoid agonists, since it does not elicit catalepsy, acute antinociception or hypothermia (Beltramo et al, 1997, 2000; Fegley et al, 2004). These differences have been attributed to the ability of AM404 to inhibit endocannabinoid transport without directly activating $\mathrm{CB}_{1}$ receptors (Beltramo et al, 1997, 2000). Recently, the existence of an endocannabinoid transport system has been questioned in favor of a simple diffusion mechanism, whereby anandamide accumulation may be solely driven by an inward concentration gradient maintained by FAAHmediated hydrolysis (Glaser et al, 2003). In this context, the actions of AM404 have also been ascribed to its ability to serve as a FAAH substrate and to compete with anandamide for FAAH activity. However, the discovery that genetic deletion of FAAH does not affect anandamide internalization in neurons argues against this possibility and in favor of the transporter hypothesis (Fegley et al, 2004; Alger, 2004; Ortega-Gutierrez et al, 2004). Additional support to this hypothesis comes from the recent discovery of potent nonaliphatic inhibitors of endocannabinoid transport, which has led to the identification of a high-affinity binding site presumably involved in the transport process (Moore et al, 2005). Noteworthy, the effects produced by AM404 are markedly different from those exerted by the FAAH inhibitor URB597 in at least two respects. First, AM404 does not affect brain levels of OEA and PEA, which are enhanced by URB597 (Kathuria et al, 2003; Fegley et al, 2005). Second, although AM404 mirrors the anxiolytic-like effects of URB597 (Kathuria et al, 2003), the 
latter does not exert any significant motivational effect in the CPP model, irrespective of housing conditions (Gobbi et al, 2005).

In addition to its inhibitory actions on anandamide transport, AM404 interacts in vitro with several unrelated pharmacological targets, such as vanilloid TRPV1 receptors (Zygmunt et al, 2000) and sodium channels (Nicholson et al, 2003). While the in vivo relevance of these effects is still unclear, we cannot rule out that they might contribute to the pharmacological properties of AM404. Nevertheless, the ability of selective doses of the $\mathrm{CB}_{1}$ receptor antagonist rimonabant to prevent the anxiolytic-like actions of AM404 suggests that such actions can be ascribed to anandamidemediated activation of $\mathrm{CB}_{1}$ receptors. To date, AM404 remains the best characterized among a small series of endocannabinoid transport inhibitors that have been developed. Indeed, the compound AM1172 (Fegley et al, 2004) also acts as a direct partial agonist of $\mathrm{CB}_{1}$ receptors, while other agents, such as VDM11, have been shown to interact with multiple targets (Kelley and Thayer, 2004). UCM707 induces hypomotility and antinociception (de Lago et al, 2002), but its impact on behavior is still incompletely documented. Thus, the compounds mentioned above offer little or no advantage over AM404 for in vivo studies. The recent availability of new anandamide transport inhibitors, such as LY2183240 (Moore et al, 2005), will allow a more detailed characterization of this target in the future. In conclusion, while our results point to the anandamide transport system as a target for anxiolytic drugs, they also highlight the need to fully characterize this system at the molecular level, and to develop more advanced probes to validate its therapeutic potential.

\section{ACKNOWLEDGEMENTS}

The present study was supported by grants from National Institute on Drug Abuse (DA-12447 and DA-3412) and the National Alliance for Research on Schizophrenia and Depression (to DP), and Ministero dell'Istruzione, Università e Ricerca (to VC and GLG). MB was a NIDA INVEST fellow. PC was an Italian Society of Pharmacology fellow. We thank Oliver Arguello and Marco Orrù for experimental assistance.

\section{REFERENCES}

Abduljawad KA, Langley RW, Bradshaw CM, Szabadi E (1997). Effects of clonidine and diazepam on the acoustic startle response and on its inhibition by 'prepulses' in man. $J$ Psychopharmacol 11: 29-34.

Alger BE (2004). Endocannabinoids: getting the message across. Proc Natl Acad Sci USA 101: 8512-8513.

Azad SC, Monory K, Marsicano G, Cravatt BF, Lutz B, Zieglgansberger $\mathrm{W}$ et al (2004). Circuitry for associative plasticity in the amygdala involves endocannabinoid signaling. J Neurosci 24: 9953-9961.

Bahri T, Amir T (1994). Effect of hashish on vigilance performance. Percept Mot Skills 78: 11-16.

Beinfeld MC, Connolly K (2001). Activation of CB1 cannabinoid receptors in rat hippocampal slices inhibits potassium-evoked cholecystokinin release, a possible mechanism contributing to the spatial memory defects produced by cannabinoids. Neurosci Lett 301: 69-71.
Beltramo M, de Fonseca FR, Navarro M, Calignano A, Gorriti MA, Grammatikopoulos G et al (2000). Reversal of dopamine $\mathrm{D}(2)$. receptor responses by an anandamide transport inhibitor. J Neurosci 20: 3401-3407.

Beltramo M, Stella N, Calignano A, Lin SY, Makriyannis A, Piomelli D (1997). Functional role of high-affinity anandamide transport, as revealed by selective inhibition. Science 277: 1094-1097.

Bortolato M, Aru GN, Frau R, Orru M, Luckey GC, Boi G et al (2005). The CB receptor agonist WIN 55,212-2 fails to elicit disruption of prepulse inhibition of the startle in SpragueDawley rats. Psychopharmacology 177: 264-271.

Bowling SL, Bardo MT (1994). Locomotor and rewarding effects of amphetamine in enriched, social, and isolate reared rats. Pharmacol Biochem Behav 48: 459-464.

Cagiano R, Barfield RJ, White NR, Pleim ET, Weinstein M, Cuomo $\mathrm{V}$ (1988). Subtle behavioural changes produced in rat pups by in utero exposure to haloperidol. Eur J Pharmacol 157: 45-50.

Cahill L, McGaugh JL (1998). Mechanisms of emotional arousal and lasting declarative memory. Trends Neurosci 21: 294-299.

Cravatt BF, Demarest K, Patricelli MP, Bracey MH, Giang DK, Martin BR et al (2001). Supersensitivity to anandamide and enhanced endogenous cannabinoid signaling in mice lacking fatty acid amide hydrolase. Proc Natl Acad Sci USA 98: 9371-9376.

Cravatt BF, Giang DK, Mayfield SP, Boger DL, Lerner RA, Gilula NB (1996). Molecular characterization of an enzyme that degrades neuromodulatory fatty-acid amides. Nature 384: 83-87.

D'Souza DC, Abi-Saab WM, Madonick S, Forselius-Bielen K, Doersch A, Braley G et al (2005). Delta-9-tetrahydrocannabinol effects in schizophrenia: implications for cognition, psychosis, and addiction. Biol Psychiatr 57: 594-608.

de Lago E, Fernandez-Ruiz J, Ortega-Gutierrez S, Viso A, LopezRodriguez ML, Ramos JA (2002). UCM707, a potent and selective inhibitor of endocannabinoid uptake, potentiates hypokinetic and antinociceptive effects of anandamide. Eur J Pharmacol 449: 99-103.

Désarnaud F, Cadas H, Piomelli D (1995). Anandamide amidohydrolase activity in rat brain microsomes. Identification and partial characterization. J Biol Chem 270: 6030-6035.

Di Marzo V, Fontana A, Cadas H, Schinelli S, Cimino G, Schwartz JC et al (1994). Formation and inactivation of endogenous cannabinoid anandamide in central neurons. Nature 372: 686-691.

Fegley D, Gaetani S, Duranti A, Tontini A, Mor M, Tarzia G et al (2005). Characterization of the fatty acid amide hydrolase inhibitor cyclohexyl carbamic acid $3^{\prime}$-carbamoyl-biphenyl-3-yl ester (URB597). Effects on anandamide and oleoylethanolamide deactivation. J Pharmacol Exp Ther 313: 352-358.

Fegley D, Kathuria S, Mercier R, Li C, Goutopoulos A, Makriyannis A et al (2004). Anandamide transport is independent of fattyacid amide hydrolase activity and is blocked by the hydrolysisresistant inhibitor AM1172. Proc Natl Acad Sci USA 101: 87568761.

Fernandez-Espejo E, Galan-Rodriguez B (2004). Sensorimotor gating in mice is disrupted after AM404, an anandamide reuptake and degradation inhibitor. Psychopharmacology 175: 220-224.

Freund TF, Katona I, Piomelli D (2003). Role of endogenous cannabinoids in synaptic signaling. Physiol Rev 83: 1017-1066.

Gardner EL (2005). Endocannabinoid signaling system and brain reward: emphasis on dopamine. Pharmacol Biochem Behav 81: 263-284.

Gerdeman GL, Ronesi J, Lovinger DM (2002). Postsynaptic endocannabinoid release is critical to long-term depression in the striatum. Nat Neurosci 5: 446-451.

Gifford AN, Bruneus M, Gatley SJ, Lan R, Makriyannis A, Volkow ND (1999). Large receptor reserve for cannabinoid actions in the central nervous system. J Pharmacol Exp Ther 288: 478-483.

Giuffrida A, Parsons LH, Kerr TM, Rodriguez de Fonseca F, Navarro M, Piomelli D (1999). Dopamine activation of 
endogenous cannabinoid signaling in dorsal striatum. Nat Neurosci 2: 358-363.

Glaser ST, Abumrad NA, Fatade F, Kaczocha M, Studholme KM, Deutsch DG (2003). Evidence against the presence of an anandamide transporter. Proc Natl Acad Sci USA 100: 42694274.

Gobbi G, Bambico FR, Mangieri R, Bortolato M, Campolongo P, Solinas $\mathrm{M}$ et al (2005). Antidepressant-like activity and modulation of brain monoaminergic transmission by blockade of anandamide hydrolysis. Proc Natl Acad Sci USA 102: 1862018625.

Griebel G, Simiand J, Serradeil-Le Gal C, Wagnon J, Pascal M, Scatton B et al (2002). Anxiolytic- and antidepressant-like effects of the non-peptide vasopressin $\mathrm{V} 1 \mathrm{~b}$ receptor antagonist, SSR149415, suggest an innovative approach for the treatment of stress-related disorders. Proc Natl Acad Sci USA 99: 63706375.

Haller J, Varga B, Ledent C, Freund TF (2004). CB1 cannabinoid receptors mediate anxiolytic effects: convergent genetic and pharmacological evidence with CB1-specific agents. Behav Pharmacol 15: 299-304.

Hill MN, Gorzalka BB (2005). Pharmacological enhancement of cannabinoid CB (1) receptor activity elicits an antidepressantlike response in the rat forced swim test. Eur Neuropsychopharmacol 15: 593-599.

Hillard CJ, Edgemond WS, Campbell WB (1995). Characterization of ligand binding to the cannabinoid receptor of rat brain membranes using a novel method: application to anandamide. J Neurochem 64: 677-683.

Hillard CJ, Edgemond WS, Jarrahian A, Campbell WB (1997). Accumulation of $\mathrm{N}$-arachidonoylethanolamine (anandamide). into cerebellar granule cells occurs via facilitated diffusion. J Neurochem 69: 631-638.

Hillard CJ, Jarrahian A (2003). Cellular accumulation of anandamide: consensus and controversy. Br J Pharmacol 140: 802-808.

Hohmann AG, Suplita RL, Bolton NM, Neely MH, Fegley DB, Mangieri RA et al (2005). An endocannabinoid mechanism for stress-induced analgesia. Nature 435: 1108-1112.

Hollister LE (1998). Health aspects of cannabis: revisited. Int $J$ Neuropsychopharmacol 1: 71-80.

Justinova Z, Goldberg SR (2005). The abuse potential of the endocannabinoid transport inhibitor AM404: self-administration by squirrel monkeys. 15th Annual Symposium on the cannabinoids, 2005, Clearwater, USA.

Justinova Z, Solinas M, Tanda G, Redhi GH, Goldberg SR (2005). The endogenous cannabinoid anandamide and its synthetic analog $\mathrm{R}(+)$-methanandamide are intravenously self-administered by squirrel monkeys. J Neurosci 25: 5645-5650.

Kathuria S, Gaetani S, Fegley D, Valino F, Duranti A, Tontini A et al (2003). Modulation of anxiety through blockade of anandamide hydrolysis. Nat Med 9: 76-81.

Kelley BG, Thayer SA (2004). Anandamide transport inhibitor AM404 and structurally related compounds inhibit synaptic transmission between rat hippocampal neurons in culture independent of cannabinoid CB1 receptors. Eur J Pharmacol 496: 33-39.

Koelega HS (1989). Benzodiazepines and vigilance performance: a review. Psychopharmacology 98: 145-156.

Larsson F, Winblad B, Mohammed AH (2002). Psychological stress and environmental adaptation in enriched $v s$ impoverished housed rats. Pharmacol Biochem Behav 73: 193-207.

Lichtman AH, Leung D, Shelton CC, Saghatelian A, Hardouin C, Boger DL et al (2004). Reversible inhibitors of fatty acid amide hydrolase that promote analgesia: evidence for an unprecedented combination of potency and selectivity. J Pharmacol Exp Ther 311: 441-448.

Moore SA, Nomikos GG, Dickason-Chesterfield AK, Schober DA, Schaus JM, Ying BP et al (2005). Identification of a high-affinity binding site involved in the transport of endocannabinoids. Proc Natl Acad USA 102: 17852-17857.

Navarro M, Hernandez E, Munoz RM, del Arco I, Villanua MA, Carrera MR et al (1997). Acute administration of the CB1 cannabinoid receptor antagonist SR 141716A induces anxietylike responses in the rat. Neuroreport 8: 491-496.

Nestler EJ, Barrot M, DiLeone RJ, Eisch AJ, Gold SJ, Monteggia LM (2002). Neurobiology of depression. Neuron 34: 13-25.

Nicholson RA, Liao C, Zheng J, David LS, Coyne L, Errington AC et al (2003). Sodium channel inhibition by anandamide and synthetic cannabimimetics in brain. Brain Res 978: 194-204.

Ortega-Gutierrez S, Hawkins EG, Viso A, Lopez-Rodriguez ML, Cravatt BF (2004). Comparison of anandamide transport in FAAH wild-type and knockout neurons: evidence for contributions by both FAAH and the $\mathrm{CB} 1$ receptor to anandamide uptake. Biochemistry 43: 8184-8190.

Palmer SL, Thakur GA, Makriyannis A (2002). Cannabinergic ligands. Chem Phys Lipids 121: 3-19.

Patel S, Roelke CT, Rademacher DJ, Cullinan WE, Hillard CJ (2004). Endocannabinoid signaling negatively modulates stressinduced activation of the hypothalamic-pituitary-adrenal axis. Endocrinology 145: 5431-5438.

Pellow S, Chopin P, File SE, Briley M (1985). Validation of open:closed arm entries in an elevated plus-maze as a measure of anxiety in the rat. $J$ Neurosci Methods 14: 149-167.

Piomelli D (2005). The endocannabinoid system: a drug discovery perspective. Curr Opin Investig Drugs 6: 672-679.

Piomelli D, Beltramo M, Glasnapp S, Lin SY, Goutopoulos A, Xie $\mathrm{XQ}$ et al (1999). Structural determinants for recognition and translocation by the anandamide transporter. Proc Natl Acad Sci USA 96: 5802-5807.

Renner MJ, Rosenzweig MR (1987). The golden-mantled ground squirrel (Spermophilus lateralis). As a model for the effects of environmental enrichment in solitary animals. Dev Psychobiol 20: $19-24$

Smith MA, Bryant PA, McClean JM (2003). Social and environmental enrichment enhances sensitivity to the effects of kappa opioids: studies on antinociception, diuresis and conditioned place preference. Pharmacol Biochem Behav 76: 93-101.

Steffens M, Szabo B, Klar M, Rominger A, Zentner J, Feuerstein TJ (2003). Modulation of electrically evoked acetylcholine release through cannabinoid CB1 receptors: evidence for an endocannabinoid tone in the human neocortex. Neuroscience 120: 455-465.

Swerdlow NR, Braff DL, Geyer MA (2000). Animal models of deficient sensorimotor gating: what we know, what we think we know, and what we hope to know soon. Behav Pharmacol 11: 185-204.

Takahashi LK, Ho SP, Livanov V, Graciani N, Arneric SP (2001). Antagonism of CRF2 receptors produces anxiolytic behavior in animal models of anxiety. Brain Res 902: 135-142.

Tzavara ET, Wade M, Nomikos GG (2003). Biphasic effects of cannabinoids on acetylcholine release in the hippocampus: site and mechanism of action. J Neurosci 23: 9374-9384.

Ueda N, Kurahashi Y, Yamamoto S, Tokunaga T (1995). Partial purification and characterization of the porcine brain enzyme hydrolyzing and synthesizing anandamide. J Biol Chem 270: 23823-23827.

Urigüen L, Perez-Rial S, Ledent C, Palomo T, Manzanares J (2004). Impaired action of anxiolytic drugs in mice deficient in cannabinoid CB1 receptors. Neuropharmacology 46: 966-973.

Weidenfeld J, Feldman S, Mechoulam R (1994). Effect of the brain constituent anandamide, a cannabinoid receptor agonist, on the hypothalamo-pituitary-adrenal axis in the rat. Neuroendocrinology 59: 110-112.

Zygmunt PM, Chuang H, Movahed P, Julius D, Hogestatt ED (2000). The anandamide transport inhibitor AM404 activates vanilloid receptors. Eur J Pharmacol 396: 39-42. 